\title{
Soft Law Instruments in Public Law
}

\author{
Alexandre Flückiger
}

\subsection{INTRODUCTION}

In Switzerland, the principle of legality establishes that state activity is based on, and limited by, law (Article 5, Swiss Constitution). Its function is to ensure that the democratic will expressed by legislators is implemented by an administration that does not act in an emotional or capricious manner. The instruments available to the state, and through which it acts, are laws, decisions, and contracts, along with the actions it takes to plan and coordinate individuals working together. It is characteristic of such acts that they are legally binding.

Administrative activity is not exhausted by the aforementioned legal acts, however. In fact, administrative practices manifest modes more suited to governance: preferring incentives over obligations, citizen cooperation rather than unilateral decisions, and coordinating multiple actors to the detriment of maintaining a hierarchical order. Such instruments are frequently grouped under the label 'soft law'-in French, droit souple Conseil d'Etat 2013; Hachez et al. 2013.

Soft law has often performed an experimental function, to test a possible future legal rule (for 'green' law, see Abi-Saab 1997: 207 et seq., for

\footnotetext{
A. Flückiger $(\bowtie)$

Faculty of Law, University of Geneva, Geneva, Switzerland e-mail: alexandre.flueckiger@unige.ch

(C) The Author(s) 2019

A. Ladner et al. (eds.), Swiss Public Administration, Governance and Public Management, https://doi.org/10.1007/978-3-319-92381-9_7
} 
'pre-law', Peters 2011: 34). The state can thus accustom addressees to a new standard which, once sufficiently matured, may become obligatory. An example is the use of seat belts: they were recommended before they became mandatory. Soft law thus guides the behavior of citizens without imposing a legal obligation. It does not replace traditional administrative activity but instead complements and strengthens it in areas where more traditional modes of governance reach their limits (Mader and Rütsche 2004: 18 et seq.; Morand 1999).

The development of this kind of state action, which is at the fringes of the law, poses difficulties for jurists. Indeed, if the ability of soft law to achieve results - in other words, its effectiveness - is likely to legitimize a remedy for a problem, its democratic foundation totters. In fact, the principle of legality, at least initially, was not designed to legitimize such flexible instruments. In addition, the limited formal requirements for carrying out soft law measures make it possible to circumvent the sluggishness of administrative or parliamentary procedures, dampen the resistance of political actors to new policies, prevent adopting regulations which are too binding or, in certain domains, compensate for an absence of competence to pass obligatory measures. From the point of view of legitimacy, this characteristic of soft law instruments is particularly problematic, since under the rule of law, efficiency criteria cannot be allowed to supersede legality.

In the Swiss case, the legal system has a tendency to tolerate or even establish mechanisms of administrative action under soft law. The Swiss Federal Supreme Court even defends this practice: 'It is not necessary that every governmental intervention take the form of a decision. If so, it would affect the proper functioning of the administration. It is often indispensable that the authorities proceed informally' (Decision of the Federal Supreme Court of 9 April 2002: ATF 128 II 156, 163). This flexibility can be understood as an application of the principle of proportionality, as Article 5 of the Swiss Constitution notes that 'state activities must be ... proportionate to the ends sought'. The Swiss legal system thus evinces a gradual normativity that reconciles the need for flexibility on the part of the administration. This is an essential ingredient to ensure a degree of efficiency and legitimacy, one indispensable for ensuring a democratic governance of the rule of law.

One thus needs to examine this type of instrument at the disposal of Swiss public administration. To specify this notion of soft law and identify the legal issues involved, we use a typology that covers differing types of state instruments in Swiss public law (Sect. 7.2). Next, we look at the legal 
effects (potentially) generated when public authorities use this type of instrument (Sect. 7.3). Then, we turn to how effective they are for the functioning of the state (Sect. 7.4). At the end, we return to the need, within the Swiss constitutional framework, to both guarantee the legitimacy of soft law and maintain its effectiveness (Sect. 7.5).

\subsection{A Legal Typology of Non-obligatory State INSTRUMENTS}

One can begin with the observation that non-binding state instruments can change the behavior of individuals either by means of a text (more formally, as 'acts of non-obligatory declaration') or by de facto acts ('material acts in the narrow sense'). However, in the case of the former, they can be enacted unilaterally by the state (Sect. 7.2.1) or in a concerted manner (Sect. 7.2.2).

They thus resemble classic legal acts. Like legal norms, they also contain norms of behavior. In the case of legal acts, the norms are mandatory and must be followed. In the case of 'acts of non-obligatory declaration', however, the norms are only recognized inasmuch as they are acknowledged by their addressees. Standards, in their non-legal sense, are not necessarily imperative in such cases. Finally, while such 'acts of non-obligatory declaration' contain rules which may or may not be followed, 'de facto acts' consist of specific actions and contain no norms (Moor and Poltier 2011: 28 et seq.) (Sect. 7.2.3).

\subsubsection{Unilateral Non-obligatory Acts}

The principal unilateral non-obligatory act at the disposal of the state is to make recommendations; a number of other special cases also illustrate this.

\subsubsection{Recommendations}

Recommendations are declarations which suggest a certain behavior should be followed. They take many different forms. Behind this diversity lie different degrees of emphasis; a warning has a stronger character than a wish or simply a piece of advice.

Giving a recommendation is a classic instrument in international public law and EU law. The resolutions and declarations adopted by the United Nations General Assembly, the most famous of which is the 1948 Universal Declaration of Human Rights, are recommendations, as are the various 
recommendations made by the Council of Europe. Similarly, declarations made at international conferences, such as at the Rio Summit on Environment and Development in 1992, or the Bologna Declaration about higher education in 1999, are also recommendations (Daillier et al. 2009: 416 et seq.; Guzman and Meyer 2010; Shelton 2008). In European law, recommendations and opinions have been institutionalized, though here too, these acts are not binding (Article 288 of the Treaty on the Functioning of the EU). Thus, the Charter of Fundamental Rights of the European Union was not legally binding before the Lisbon Treaty came into force (Nowak 2011: 134 et seq.). At the international level, some rules which take the form of a recommendation are also produced outside of government. These may come from private, semi-public, or hybrid actors and their influence on internal law may be decisive (Pauwelyn et al. 2012). To some authors, they even appear to be a kind of global administrative law (Cassese 2005).

As will be shown later, recommendations have become a classic instrument in Swiss law. In terms of formulating behavioral rules, recommendations may be either explicit or implicit in nature. Thus, when they directly state what the recommended behavior is, they will be described as explicit. Some examples are provided in Table 7.1 (Moor et al. 2012: 404 et seq.).

However, when state instruments point toward following a behavior without expressing it explicitly, the behavior to be followed stems implicitly from the instrument; its purpose, more or less obviously, amounts to a recommendation. Thus, through the publicity a public authority gives to its exemplary behavior, it can exhort individuals to adapt their conduct (Morand 1999: 178). Furthermore, a public administration thus demonstrates the feasibility of adopting the conduct, and thus increases its credibility.

For example, in public procurement, the incentive effect is reinforced when the state uses its power to issue contracts. They serve their own recommendations and are contained, in turn, in their public policy objectives. Although the potential contractors remain free not to conform to the state's new requirements, they then take the risk of being excluded from the public market (Manfrini 1991). In keeping with the principles of transparency, equal treatment, the prohibition of discrimination, and free competition, the state may lay out certain criteria, particularly ecological or social, before awarding a public contract (Rodondi 2001). 
Table 7.1 Typology of recommendations

\begin{tabular}{|c|c|}
\hline $\begin{array}{l}\text { Recommendations } \\
\text { strictly speaking }\end{array}$ & $\begin{array}{l}\text { The grape varieties recommended for cultivation in Switzerland } \\
\text { (Art. 3, Ordinance on Grape Varieties) }\end{array}$ \\
\hline Alerts & Public warning (Art. 54, Foodstuffs Act) \\
\hline Advice & $\begin{array}{l}\text { The waters protection agencies shall provide advice to the } \\
\text { authorities and to private individuals (Art. } 50 \text { II, Waters } \\
\text { Protection Law) }\end{array}$ \\
\hline Notice & $\begin{array}{l}\text { The Competition Commission shall provide other authorities with } \\
\text { expert reports on competition law issues of general importance } \\
\text { (Art. } 47 \text {, Cartel Law) }\end{array}$ \\
\hline Notification & $\begin{array}{l}\text { The office notifies the insured about any final decision it intends } \\
\text { to take on a claim for benefits (Art. } 57 \text { a, Disability Insurance Act) }\end{array}$ \\
\hline $\begin{array}{l}\text { Conclusions of } \\
\text { certain reports }\end{array}$ & $\begin{array}{l}\text { The report of the study must include the following information: } \\
\text { Conclusions and recommendations (Art. } 8 \text { II, HIV Studies } \\
\text { Ordinance) }\end{array}$ \\
\hline Invitations & $\begin{array}{l}\text { The office invites organizations which have concluded an } \\
\text { agreement, along with those enterprises engaged in distribution } \\
\text { and projection in the respective film region and which have not } \\
\text { finalized an agreement concerning diversity in their offer, to } \\
\text { submit their agreements in writing (Art. } 5 \text { I, Film Ordinance) }\end{array}$ \\
\hline Wishes & $\begin{array}{l}\text { The International Telecommunications Union formulate } \\
\text { recommendations and opinions }[\ldots] \text { concerning } \\
\text { telecommunication matters (Art. } 1 \text { II h, ITU Constitution) }\end{array}$ \\
\hline
\end{tabular}

Incentive taxes in the context of the environment operate the same way (Oberson and Maraia 2010). Individuals are free to put vegetable peelings in their garbage bags, but if the bag itself is taxed, it serves as a financial encouragement or incentive for individuals to sort their waste a little more carefully.

Labeling or certification requirements (Article 43a, Environmental Protection Act or EPA) serve to guide the choices market actors make. They can certainly ignore the requirements, but may then find themselves at a competitive disadvantage in obtaining public contracts (Subilia-Rouge 2010: N. 73 et seq.), or find themselves in difficulties when monitoring or controlling procedures are carried out.

Awards and prizes to citizens from the authorities (Article 7, Film Act) are an indirect recommendation to follow the rewarded behavior. Training can also profoundly influence an individuals' behavior, at least over the longer term. What is taught acts like a recommendation for those who are taught when public authorities include this means in their toolkit (Delley 1991). 
Depending on the context, even objectively presented information or description may have an incentive effect. The scientific observation that 'smoking kills', when affixed to a cigarette package, can be interpreted as a recommendation not to smoke.

However, unilateral, non-obligatory acts are not exhausted by recommendations alone. A series of special cases attests to this.

\subsubsection{Special Cases}

Many special cases demonstrate that non-obligatory acts take a different form than recommendations. Thus, in areas where international relations are strongly intertwined, foreign law can have a place in national law like that of soft law. Switzerland's adoption of EU law provides an illustration. As a non-EU member, Switzerland is not obligated to follow EU law. Nevertheless, it behooves - and helps-the Swiss to follow EU law, as appropriate. The same could be said of domestic draft law: it can exert real influence in helping interpret a rule, justify a litigious legal basis, or anticipate potential implementation issues (Flückiger 2004: 205 et seq.). These are not examples of recommendations, as neither a foreign law nor a domestic draft law in itself has a recommendatory purpose.

Swiss law also produces administrative orders, which encompass circulars, directives, instructions, guides, and similar material. These are not binding on the administered but are binding on those who administer (Moor et al. 2012: 420 et. seq.). The former may be interested in complying almost by reflex, particularly when such orders affect their legal situation.

In urban planning, certain actions are obligatory, the best known of which are land allocation plans (Section 21, Land Use Planning Act). Many other actions are only partly required, or not required at all, and in this case, they bind only the authorities (Moor and Poltier 2011: 578 et seq.).

\subsubsection{Concerted Non-obligatory Acts}

The soft law toolkit includes concerted acts, referred to here as arrangements. This notion of concerted non-obligatory acts is also known in international public law, and are called gentlemen's agreements, nonbinding agreements, joint statements, charters, arrangements, codes of conduct, and the like (Daillier et al. 2009: 422 et seq.; Pauwelyn et al. 2012; on codes of conduct specifically, see Keller 2008). Such acts unite flexibility with cooperation, two typical features of governance. They are 
the favored expressions of self-regulation but should not be confounded with it. Numerous classifications are imaginable, but we focus here on concerted acts which have a degree of linkage to legal acts.

\subsubsection{Preparing a Legal Act}

Certain arrangements may be made in conjunction with preparing a legal act. We can mention (Flückiger 2004: 207 et seq.):

- a declaration of intent describing reciprocal concessions;

- an agreement on a draft decision;

- a consultation charter intended to frame the negotiations in construction procedures;

- informal arrangements in the context of legislative consultation procedures.

Such arrangements may also be concluded between public authorities (see Article 3la EPA, which provides for a mediation procedure if the cantons cannot agree).

\subsubsection{Implementing a Legal Act}

Other arrangements are meant to help implement the legal rules, such as those for environmental audits in which the state agrees to reduce the intensity of surveillance in return for commitments by a company to implement an audit and certification system (Subilia-Rouge 2010: N. 51).

\subsubsection{Preventing a Legal Act}

Some gentlemen's agreements are concluded with the aim of preventing the state from carrying out a legal act. In return, individuals provide a service which makes it possible to respond more appropriately to the problem that the legal act was meant to resolve. In legal terms, if the renunciation of the power to legislate does not rest on a legal basis, the state can always intervene. In this situation, individuals could not avail themselves of this renunciation should the state nevertheless decide to legislate (Decision of the Federal Supreme Court of 7 July 1992: ATF 118 lb. 367, 380, $\$ 9$ b and d). This type of arrangement is therefore based on a dual relationship. On the one hand, it is a relationship - in the nature of a recommendation-between the state and private individuals. On the other hand, it is a link-at times obligatory-between individuals that makes it possible to implement the substituted mechanism (Errass 2010: 62 et seq.). 
One should note here that codes of professional ethics are very informal precursors of this type of arrangement. They make it possible to avoid having public authorities themselves adopting rules to monitor the profession. The Swiss National Bank used such informal arrangements as early as the 1930s, and they were gradually integrated into ordinary law and thus lost their initial informality. More recently, public authorities have concluded many gentlemen's agreements (Brunner 2004).

Swiss law provides several examples of the gradual formalization of the vertical relationship between the state and individuals:

- In environmental matters, the law now requires the public authorities to work with private sector organizations to enforce the law. The public authorities are free to encourage sectoral agreements by indicating targets and timelines. However, before issuing implementation requirements, they must examine voluntary private sector measures. Wherever possible and necessary, sectoral agreements are to be incorporated into the implementing regulations, in whole or in part (Art. 4la, EPA).

- 'Damoclean' laws institutionalize the vertical relationship of an agreement by specifying the objectives to be attained, the state's commitment to not legislate pending finding a self-regulating solution, and its substitution mechanism should the specified objectives not be reached. The $\mathrm{CO}_{2}$ Emissions Reduction Act was designed in this manner (other examples can be found in Flückiger 2005). There are other cases which are simply meant to keep the state from making a decision in a particular case.

- The most questionable, in a legal sense, are those agreements in which the public authorities tolerate an activity in exchange for specific actions to be carried out by the citizens. To try to frame such practices in the most sensitive areas, legislators have formalized the question. This is the case when relief is granted by the public authorities when the remediation of an ecologically non-compliant installation is disproportionate (Article 17 (1), EPA).

- By contrast, there are agreements to nullify illegal situations, such as informal agreements reached to clean up contaminated sites. The public authorities should try to reach an agreement with the persons directly affected and may renounce making a formal decision if enforcement of the measures can be otherwise assured (Article 23, Contaminated Sites Ordinance). 


\subsubsection{Material Acts}

Among non-obligatory state acts, one can also speak of material acts in the narrow sense. Their common point is their use of concrete measures. Examples include building traffic obstructions to mitigate traffic flows, installing gates or barriers to prevent trespassing, installing mechanisms which keep vehicles from starting until the cars' seat belts have been fastened, or regulating the Internet by using its technical architecture.

Such material acts in the narrow sense are not legally binding but are instead concrete actions. Unlike mandatory or voluntary norms, acts of this kind influence behavior through facts rather than declarations. One can therefore say this type of state action is neither 'law' nor even 'soft'. Transgression, when it is possible, provokes consequences at the level of facts. Still, depending on the case, such a transgression can be more penalizing than the transgression of a legal act. For example, repairing shock absorbers damaged by driving too quickly over a speed bump meant to slow cars down may ultimately prove more expensive than paying a fine for speeding.

\subsection{Legal Effects of Non-obligatory State Acts}

Although state actions under soft law are in principle not legally binding, they are nonetheless legally relevant (Moor et al. 2012: 410 et seq.). Indeed, they can infringe on rights, fundamental or not. Article 35 (2) of the Swiss Constitution, in fact, states that 'whoever acts on behalf of the state is bound by fundamental rights and is under an obligation to contribute to their implementation'. This ensures that material acts, in a broad sense, are subject to concrete legal control (Decision of the Federal Supreme Court of 13 November 2006: ATF 133 I 49, 56). In this case, examining non-obligatory state acts makes it possible to detect a specific normativity, one staggered in several steps.

Thus, in some very particular cases, non-obligatory state acts may become mandatory. For example, the Federal Food Act empowered the Federal Council to order that certain sections of the Food Manual are binding, even though the manual itself was a recommendation (Articles $22(2)$ and (3)). Another example is provided by the Competition Commission. Indeed, given 'good faith' principles (noted in both Art. 5 and Art. 9 of the Swiss Constitution), this Commission is obliged to 
apply the criteria it adopts and publishes in documents called 'general notices' (see Art. 6 (1) of the Cartel Act), which are without binding force.

Legislation may also include special clauses which indirectly confer a binding force on a non-obligatory act, such as when a law states that decision $\mathrm{X}$ must be consistent with recommendation $\mathrm{Y}$, which means there is no choice but to comply with the recommendation. Thus, in constructing high-current electrical equipment, the technical recommendations of the association of Swiss electric power stations 'must be followed' (Article 7 (2), High Current Ordinance).

Less frequent are the cases in which a recommendation is included in a normative act. Here the recommendation has no direct effect on individuals. It can however bind other public authorities, especially those in a hierarchical or supervisory relationship. For example, according to the Federal Road Traffic Ordinance, car lights 'should' be on even during daylight hours (Article 31, FRTO). The Federal Office of Energy, for example, no longer has the right to make a recommendation to the contrary, on the grounds that compliance with such a measure would increase fuel consumption and increase pollution.

A governmental recommendation may also have a permissive effect, in that it legitimizes the action of those who follow it. In this case, its recipients do not commit an offense by acting in a manner which is recommended. If it was to be considered that they committed one, it would mean that the act itself is contrary to the law. This implies that such acts can be controlled by a judicial body in case of doubt as to their compatibility with legal norms.

Finally, the public authorities may define, using a legal standard or norm, the jurisdiction for adopting a non-obligatory act. Here again, such a rule does not bind the addressees. However, it has a legal effect since the public authorities still must act within the framework thus drawn. It is the same when the law incorporates such an act into a more general procedural framework. The enactment of the recommendation is then a preliminary step in a process which leads to adopting a legal act. The result is a legal effect, since the failure to enact may constitute a procedural defect. In this case, the non-obligatory act constitutes a prerequisite for the adoption of the obligatory act. For example, Article 14 of the Price Surveillance Act requires the public authority in charge to obtain a ruling from the Price Regulator when required by law. 


\subsection{The Implementation of Non-obligatory State ACTS}

When the authority resorts to governance mechanisms which are not binding, one can legitimately wonder whether these have a useful effect on society. To answer this, one needs to address the more general issue of the effectiveness of soft law (Sect. 7.4.1) and then examine the techniques which have been developed to strengthen it (Sect. 7.4.2).

\subsubsection{The Effectiveness of Soft Law}

The addressees of acts of soft law are not legally bound to follow them. Nevertheless, such acts are recognized as having a concrete effect of varying intensity (Moor et al. 2012: 415 et seq.) —and many non-binding state acts do not need to be legally binding to be regarded as politically imperative. Obedience obviously does not depend on attractiveness or fear, consequences classically sought by the law. They instead depend on moral, ethical, political, economic, or psychological considerations.

Some examples serve to illustrate the power and influence of acts of soft law. Thus, the 1999 Bologna Declaration has led to a rapid and profound reform of the practices in institutions of higher education throughout Europe even though the Declaration itself is devoid of legal force. Public administration offices or courts are also likely to use soft law to interpret legal rules, though here the effect is indirect. For example, the European Court of Human Rights has condemned Romania for violating the right everyone has 'to respect for his private and family life and his home' (Article 8, European Convention on Human Rights) on the grounds that Romania has not stopped mining for gold ore, despite the precautionary principle enshrined in the Rio Declaration, a non-obligatory act (Tatar vs. Romania, 27 January 2009, vs. 120; Ailincai 2017).

Fear of civil or criminal liability can act as a strong incentive to comply with a recommendation. Following a drowning, the head of a water park was convicted of negligent homicide, on the grounds that a CCTV camera placed underwater, as recommended by the Swiss Accident Prevention Bureau, could have prevented this death (Federal Supreme Court, Decision 6S.358/2004 of 10 November 2004, paragraphs 5.3 and 7.2). 
In some cases, the effects of soft law may be even more severe. The classic example is provided by alerts issued against defective products. Due to the potential damage to the image of the company, the publicity generated by issuing a warning (a non-obligatory act) carries greater weight than a simple notification prohibiting the distribution of a defective product (an obligatory act).

\subsubsection{Techniques for Reinforcing Effectiveness}

The state can resort to various mechanisms, both psychological and legal, to increase the effectiveness of the actions it takes. Techniques from social psychology or affective science can be particularly effective; they make tactical use of the emotions of addressees of an act by evoking feelings of fear, guilt, or desire. The use of such techniques, however, is clearly an issue in a society predicated on freedom and individual autonomy. They must therefore be justified, all the more so because of the weaker democratic legitimacy of soft law (Flückiger 2009).

Mechanisms of a legal nature can also strengthen the respect for soft law. Those to whom such soft law is directed remain free to follow them or not, but the de facto constraint can be strong, and in terms of its effects, may be indistinguishable from a legal constraint. Take the example of financial or regulatory pressure. The behavior an incentive tax or a subsidy suggests is only a recommended path, but not following it may be expensive or even jeopardize the existing system.

Legislation may also require that a recommendation be used simply as a basis for making a decision or that exemption from a recommendation be motivated (non-binding imperative clauses). Public authorities are not obliged to scrupulously follow the provisions contained in such a soft law act, but must instead use it as a basis in the decision-making process. Thus, the Federal Veterinary Office, in preparing and publishing statistics, takes international recommendations 'into account' (Article 147 II, Animal Protection Ordinance). Finally, legislators can insert a retrospective evaluation clause regarding the implementation of a nonobligatory act. Under Swiss law, for example, the federal government must 'inform' the Aircraft Accident Investigation Bureau of actions taken as a result of safety recommendations, or the reasons measures are not being taken (Art. 32 Directive on investigating aviation accidents and serious incidents). 


\subsection{Conclusion: Legitimizing Soft LaW, BEYOND EFFICIENCY}

Implementing the goals of public policy is no longer conceivable today without the use of soft law, as the Swiss case amply demonstrates. Indeed, the flexibility in adopting such instruments, combined with the effects they are likely to have, makes them indispensable in terms of efficiency.

However, as noted in the introduction, such soft law tools are problematic inasmuch as they do not enjoy the same democratic legitimacy as ordinary acts of law. If soft law had no effect, this would not pose particular problems, but as we have shown, this is not the case. Faced with this situation, it is necessary that public authorities adopt legitimization measures adapted to the particularities of soft law. One can suggest the following: the more non-obligatory acts by the state infringe on a right (at whatever level), and/or the more important their effects, the more one must ensure they are treated as equivalent to ordinary legal acts.

Specifically, a non-imperative act must be treated by the legal system almost the same way a legal act is when its effects are virtually obligatory (or very binding in fact), and when it affects a right extensively. Conversely, a non-imperative act which is devoid of effect and does not encroach on a right can have a quiet existence far from the legal constraints of the state.

In this perspective, the public authorities then need to become creative in finding ways to legitimize soft law. On the one hand, they must respect the values underlying basic principles of the rule of law: legality, public interest, proportionality, equality, and prohibiting arbitrariness. On the other hand, they must avoid codifying acts of soft law to the point of sacrificing their effectiveness.

Analysis needs to be carried out on a case-by-case basis, according to the different types of acts and the contexts in which they occur. For example, we can cite the requirement that recommendations be carried out in a way that respects the principles of objectivity and transparency, or the need for a consultation in order to guarantee an open, consensual, and participatory process when it comes to non-obligatory urban planning acts. It is also conceivable that procedural guarantees be increased (establishing a consultation process, providing a right to be heard before a recommendation is adopted, or publishing charters).

Finally, one needs to ensure soft law acts can be reviewed. Long limited to liability law, Swiss law has now been extended to allow for the judicial review of non-obligatory acts. Thus, any person with an interest worthy of 
protection can request that the public authorities refrain from illicit acts, cease trying to carry them out (or even revoke them), eliminate their consequences, or recognize their illegality. The responsible public authorities then reach a decision on this demand, one subject to appeal (Article 25a of the Federal Act on Administrative Procedure). In the case of an infringement of a fundamental right, at least one which is sufficiently grave, Article 35 (2) of the Swiss Constitution cited above imposes legal control (see also Decision of the Federal Supreme Court of 13 November 2006: ATF 133 I 49, 56).

It is not always possible to have a judge intervene, and in such cases, it is preferable to develop alternative control mechanisms, such as mediation bodies, an evaluation of public policies, or reporting to the relevant supervisory authority.

\section{REFERENCES}

Abi-Saab, G. (1997). Cours général de droit international public. Recueil des cours de l'Académie de droit international, tome 207.

Ailincai, M. (2017). La soft law est-elle l'avenir des droits fondamentaux? Revue des Droits et Libertés Fondamentaux, 20.

Brunner, U. (2004). Regulierung, Deregulierung und Selbstregulierung im Umweltrecht. Revue de droit suisse, II, 307-370.

Cassese, S. (2005). Administrative Law without the state? The challenge of global regulation. New York University Journal of International Law and Politics, 37, 663-694.

Conseil d'Etat. (2013). Le droit souple: Etude annuelle 2013. Paris.

Daillier, P., Forteau, M., \& Pellet, A. (2009). Droit international public. Paris: LGDJ.

Delley, J.-D. (1991). L'action par la formation. In C.-A. Morand (Ed.), Les instrumentsd'action de l'Etat (pp. 89-112). Basel/Frankfurt: Helbing \& Lichtenhahn.

Errass, C. (2010). Kooperative Rechtssetzung. Zurich/St. Gallen: Dike.

Flückiger, A. (2004). Régulation, dérégulation, autorégulation: l'émergence des actes étatiques non obligatoires. Revue de droit suisse, 2, 159-303.

Flückiger, A. (2005). La loi Damoclès. In B. Bovay \& M. S. Nguyen (Eds.), Mélanges Pierre Moor (pp. 233-248). Bern: Stämpfli.

Flückiger, A. (2009). Pourquoi respectons-nous la soft law? Le rôle des émotions et des techniques de manipulation. Revue européenne des sciences sociales, XLVII-144, 73-103.

Guzman, A., \& Meyer, T. (2010). International soft law. Journal of Legal Analysis, 2(1), 171-225.

Hachez, I., et al. (Eds.). (2013). Les sources du droit revisitées: Théorie des sources du droit (Vol. 4). Limal: Anthemis, Chap. II. 
Keller, H. (2008). Codes of conduct and their implementation: The question of legitimacy. In W. Rüdiger \& R. Volker (Eds.), Legitimacy in international law (pp. 219-298). Berlin: Springer.

Mader, L., \& Rütsche, B. (2004). Regulierung, Deregulierung, Selbstregulierung: Anmerkungen aus legistischer Sicht. Revue de droit suisse, 2, 3-156.

Manfrini, P.-L. (1991). Les contrats de marchés publics mis au service de la poursuite d'une politique publique. In C.-A. Morand (Ed.), Les instruments d'action et l'Etat (pp. 127-146). Basel/Frankfurt: Helbing \& Lichtenhahn.

Moor, P., \& Poltier, E. (2011). Droit administratif(Vol. II). Bern: Stämpfli.

Moor, P., Flückiger, A., \& Martenet, V. (2012). Droit administratif. Bern: Stämpfli.

Morand, C.-A. (1999). Le droit néo-moderne des politiques publiques. Paris: LGDJ.

Nowak, C. (2011). Europarecht nach Lissabon. Baden-Baden: Nomos.

Oberson, X., \& Maraia, J.-F. (2010). Remarques liminaires ad art. 35a-35c LPE, Problèmes juridiques posés par l'utilisation de taxes d'incitation. In P. Moor, A.-C. Favre, \& A. Flückiger (Eds.), Loi sur la protection de l'environnement (LPE). Bern: Stämpfli.

Pauwelyn, J., Ramses, W., \& Wouters, J. (Eds.). (2012). Informal international law-making. Oxford: Oxford University Press.

Peters, A. (2011). Soft law as a new mode of governance. In U. Diedrichs, W. Reiners, \& W. Wessels (Eds.), The dynamics of change in EZ governance (pp. 21-51). Cheltenham/Northampton: Edward Elgar Publishing.

Rodondi, O. (2001). Les critères d'aptitude et les critères d'adjudication dans les procédures de marchés publics. RDAF I, 57, 387-413.

Shelton, D. (2008). Soft law. In D. Amstrong (Ed.), Handbook of international law (pp. 68-80). London/New York: Routledge Press.

Subilia-Rouge, L. (2010). Art. 43a LPE. In P. Moor, A.-C. Favre, \& A. Flückiger (Eds.), Loi sur la protection de l'environnement (LPE). Bern: Stämpfli.

Open Access This chapter is licensed under the terms of the Creative Commons Attribution 4.0 International License (http://creativecommons.org/licenses/ by $/ 4.0 /)$, which permits use, sharing, adaptation, distribution and reproduction in any medium or format, as long as you give appropriate credit to the original author(s) and the source, provide a link to the Creative Commons license and indicate if changes were made.

The images or other third party material in this chapter are included in the chapter's Creative Commons license, unless indicated otherwise in a credit line to the material. If material is not included in the chapter's Creative Commons license and your intended use is not permitted by statutory regulation or exceeds the permitted use, you will need to obtain permission directly from the copyright holder. 